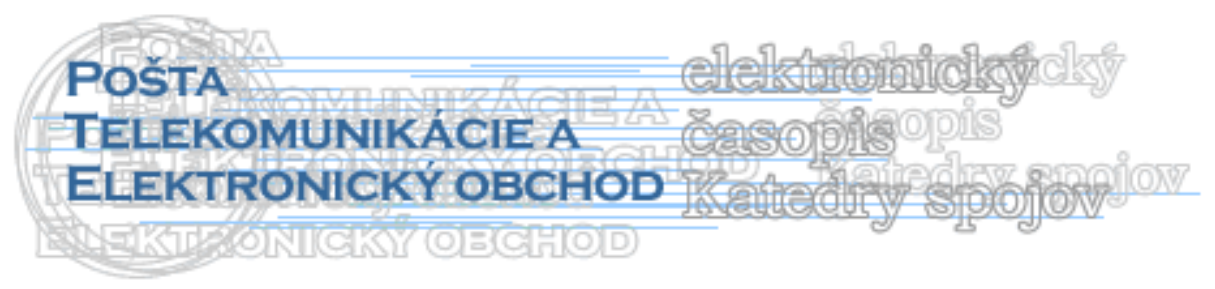

\title{
DAŇOVÁ ASIGNÁCIA
}

\author{
Lucia Krátka*
}

\section{Úvod}

Daňová asignácia je možnost'ou daňovníka rozhodnút' o smerovaní časti zaplatenej daňovej povinnosti inému príjemcovi ako je štát. Ak o použití dane alebo jej časti nerozhoduje štát ale daňovník, prestáva byt' daň daňou, pretože neplní svoj prvoradý účel, ktorým je kolektívne rozhodovanie o jej použití prostredníctvom štátu.

Daňová asignácia teda spôsobuje, že suma, ktorú asignujúci daňovník odvádza štátu ku kolektívnemu rozhodovaniu formou daní, sa potom takýmto spôsobom znižuje. Čast' dane ktorá sa odvedie štátu si zachováva povahu dane, tá čast' dane, ktorú asignujúci daňovník smeruje inému subjektu (podl'a svojho výberu) nie štátu, stráca vlastnosti dane a stáva sa beztvarou sumou peňazí s t’ažko definovatel'ným charakterom. [3]

Zavedením daňovej asignácie sa môže suma, ktorú jeden daňovník odovzdá ku kolektívnemu použitiu líšit' od sumy, ktorú ku kolektívnemu použitiu odvádza iný daňovník príjmovo rovnako situovaný. Princíp daňovej spravodlivosti (rovnaký príjem, rovnaká daň) zostáva daňovou asignáciou formálne zachovaný, avšak v skutočnosti je s ňou vo vel'kom rozpore. Nespravodlivost' spočíva v tom, že daňovníkovi, ktorý asignuje čast' dane inému príjemcovi ako je štát, sa nijako nezmenšuje prístup k statkom, ktoré financuje štát, aj ked' na ne štátu prispieva menej než neasignujúci daňovník. [3]

Rozhodujúcim faktorom pri odvádzaní daňovej povinnosti štátu je určenie statku, ktorý bude $\mathrm{z}$ daňového výnosu financovaný, jeho výška a rozsah, čo určujeme kolektívne t.j. politickou vol'bou. Asignácia tvorí teda kombináciu povinnosti odvádzat' čast' zo stanovenej dane inému subjektu ako je štát a individuálneho rozhodovania o použití tejto časti.

Daňová asignácia teda posilňuje princíp partnerstva a podporuje financovanie aktivít na úrovni regiónov a obcí. V žiadnom prípade však nemá nahradit’ žiadny spôsob podpory neštátnych neziskových organizácií ako sú štátne dotácie, daňové úl'avy.

Mechanizmus daňovej asignácie prešiel od svojho vzniku v Slovenskej republike viacerými dôležitými zmenami. Pôvodne mohli iba fyzické osoby poukázat' $1 \%$ zo svojej zaplatenej dane z príjmu v prospech prijímajúcej organizácie. Po dvoch rokoch takéhoto fungovania nastala v mechanizme prvá zásadná zmena - zvýšilo sa percento poukazovaného podielu zo spomínaného $1 \%$ na $2 \%$ a súčasne ako v jedinej krajine na svete sa umožnilo aj právnickým osobám, aby poukazovali $2 \%$ zo zaplatenej dane v prospech prijímajúcich subjektov. Možnost' asignácie dane sa neustále vyvíja. Neskôr prišli d'alšie zmeny ako je zvýšenie minimálnej sumy na poukázanie 2\% od fyzických osôb z 20 Sk (0,66 €) na 100 Sk $(3,32 €)$, zmeny $\mathrm{v}$ účeloch, na ktoré sa môžu používat' financie z $2 \%$, rozšírenie okruhu

\footnotetext{
${ }^{*}$ Ing. Lucia Krátka, Žilinská univerzita v Žiline, Fakulta prevádzky a ekonomiky dopravy a spojov, Katedra spojov, Univerzitná 1, 01026 Žilina

e-mail: kratka@fpedas.uniza.sk
} 
právnych foriem, ktoré môžu prijímat' túto čiastku, ako aj predĺženie doby na zverejnenie špecifikácie použitia financií v Obchodnom Vestníku. [4] tabul'ke:

Kto a kol'ko daroval 2\% dane v jednotlivých rokoch je znázornené v nasledujúcej

\begin{tabular}{|l|l|r|r|r|r|}
\hline \multirow{2}{*}{ Rok } & \multicolumn{2}{|c|}{ Počet darcov } & \multicolumn{2}{|c|}{ Suma (v mil. eur) } & \multirow{2}{*}{ Spolu (v mil. eur) } \\
\cline { 2 - 5 } & FO & PO & FO & PO & 30,9 \\
\hline 2005 & 418241 & 14063 & 10,4 & 20,5 & 37,3 \\
2006 & 446973 & 17740 & 11,7 & 25,6 & 42,1 \\
2007 & 408277 & 21632 & 12,8 & 29,3 & 49,1 \\
2008 & 449909 & 26691 & 15,0 & 34,1 & 45,7 \\
$2009 *$ & 501732 & 29969 & 14,5 & 31,2 & \\
\hline
\end{tabular}

*Údaje spracované k 27.7.2009

Zdroj: Vyhlásenie o poukázaní sumy vo výške 2\% zaplatenej dane. [Online]. [Citované 2010-05-09]. Dostupné na:

$<$ http://www.drsr.sk/drsr/slovak/poskytovanie_informacii/media/data/ts10_2perc.pdf>

V roku 2009 celková suma poukázaného podielu 2\% zaplatenej dane na osobitné účely predstavovala čiastku 55180 tis. EUR. Podiel 2\% zaplatenej dane na osobitné účely v roku 2009 poukázalo celkom 533331 poskytovatel'ov z toho bolo 503253 fyzických a 30078 právnických osôb. Z počtu 503253 fyzických osôb až 384396 predstavovali fyzické osoby zamestnanci, ktorí poukázali podiel zaplatenej dane formou predloženého tlačiva Vyhlásenia, 118857 fyzických osôb - daňových subjektov poukázalo podiel zaplatenej dane vyplnením Vyhlásenia, ktoré je súčast’ou daňového priznania k dani z príjmov fyzických osôb typu A a typu B. [2]

\section{Pozitíva daňových asignácií}

Daňová asignácia je jedným z nástrojov, ktorý môžu občania využívat' na spolurozhodovanie o verejnom prospechu. Rozvíjajú sa tak vzájomné vzt’ahy medzi neziskovými organizáciami a občanmi, ale aj firemná filantropia. Neziskové organizácie predstavujú svoju činnost' a prispievajú k zmene spoločenskej klímy. Týmto spôsobom sa rozvíjajú predovšetkým malé organizácie, ku ktorým sa štátna pomoc vôbec nedostane. [5]

\section{Negatíva daňových asignácií}

Náklady spojené s formálnymi náležitost’ami potrebnými na správu týchto prostriedkov môžu presiahnut' celkovú výnosnost' ako aj rozšírenie agendy kontroly neziskových organizácií. [5]

Ako sa už vyjadril rezort financií o zneužívaní peňazí rôznymi nadáciami, ktoré si založili firmy a využívali peniaze samy pre seba. Ide hlavne o skúsenosti z daňových kontrol ale aj podnety l'udí. Novela zákona preto zakazuje použit' darované peniaze na obstaranie nehnutel'ností a na reklamu, ak to nesúvisí s vymedzenou činnost'ou mimovládnej organizácie. [1]

Od 1.1.2010 nastávajú v mechanizme daňovej asignácie na Slovensku podstatné zmeny, ktoré upravuje zákon č. 504/2009, v ktorom sa mení a dopĺn̆a ustanovenie o použití podielu zaplatenej dane na osobitné účely. 


\section{Použitie podielu zaplatenej dane na osobitné účely}

Daňovník, ktorý je fyzickou osobou, je oprávnený vyhlásit' v daňovom priznaní v lehote na podanie daňového priznania alebo vo vyhlásení predloženom miestne príslušnému správcovi dane do 30. apríla po skončení zdaňovacieho obdobia, ak ide o daňovníka, ktorému zamestnávatel', ktorý je platitel'om dane, vykonal ročné zúčtovanie, že podiel zaplatenej dane do výšky $2 \%$ sa má poukázat' ním určenej právnickej osobe. [6]

Daňovník, ktorý je právnickou osobou, je oprávnený vyhlásit' v daňovom priznaní v lehote na podanie daňového priznania, že podiel zaplatenej dane do výšky $2 \%$ sa má poukázat' ním určeným prijímatel'om, ak v zdaňovacom období, ktorého sa vyhlásenie týka alebo najneskôr $\mathrm{v}$ lehote na podanie tohto daňového priznania daroval finančné prostriedky najmenej vo výške zodpovedajúcej $0,5 \%$ zaplatenej dane ním určeným daňovníkom, ktorí nie sú založení alebo zriadení na podnikanie, ak daňovník neposkytol tieto finančné prostriedky ako dar najmenej vo výške 0,5\% zaplatenej dane, je oprávnený vyhlásit' v daňovom priznaní v lehote na podanie daňového priznania, že podiel zaplatenej dane sa má poukázat' ním určeným prijímatel'om len do výšky $1,5 \%$ zaplatenej dane. [4]

Podiel zaplatenej dane je najmenej 3,32 eura, ak je daňovníkom fyzická osoba, a 8,30 eura pre jedného prijímatel’a, ak je daňovníkom právnická osoba.

Vyhlásenie o poukázaní podielu zaplatenej dane za zdaňovacie obdobie, za ktoré sa daň platí, obsahuje:

a. presné označenie daňovníka, ktorý podáva vyhlásenie,

b. sumu zodpovedajúcu podielu zaplatenej dane,

c. zdaňovacie obdobie, ktorého sa vyhlásenie týka,

d. identifikačné údaje prijímatel'a alebo prijímatel'ov,

e. uvedenie sumy pripadajúcej na každého prijímatel’a.

Podiel zaplatenej dane možno poskytnút' prijímatel'ovi, ktorým je:

a. občianske združenie,

b. nadácia,

c. neinvestičný fond,

d. nezisková organizácia poskytujúca všeobecne prospešné služby,

e. účelové zariadenie cirkvi a náboženskej spoločnosti,

f. organizácia s medzinárodným prvkom,

g. Slovenský Červený kríž,

h. subjekty výskumu a vývoja,

i. Protidrogový fond,

j. Fond rozvoja odborného vzdelávania a prípravy.

Podiel zaplatenej dane možno poskytnút' prijímatel'ovi a použit' len na účely, ktoré sú predmetom jeho činnosti, ak predmetom jeho činnosti sú:

a. ochrana a podpora zdravia; prevencia, liečba, resocializácia drogovo závislých v oblasti zdravotníctva a sociálnych služieb,

b. podpora a rozvoj telesnej kultúry,

c. poskytovanie sociálnej pomoci,

d. zachovanie kultúrnych hodnôt,

e. podpora vzdelávania, 
f. ochrana l’udských práv,

g. ochrana a tvorba životného prostredia,

h. veda a výskum. [6]

Asignácia dane má však u právnických osôb postupne zaniknút'. Týmto zásahom by sa mali zvýšit' príjmy štátneho rozpočtu a zastavit' zneužívanie takto darovaných peňazí. Nahradit' by ju mali priame finančné dary zo ziskov firiem. Štát daňovou asignáciou prichádza o milióny eur. Tento výpadok by sa mal v najbližších rokoch znižovat'. Ak budú chciet' právnické osoby poukázat' $\mathrm{v}$ daňovom priznaní za rok 2010 dve percentá $\mathrm{z}$ ich dane tretiemu subjektu, budú musiet' preukázat', že prijímatel'ovi dane zároveň dali aj finančný dar $\mathrm{z}$ ich majetku vo výške pol percenta dane. Ak tak neurobia štát na účet prijímatel'a prevedie len $1,5 \% \mathrm{z}$ odvedenej dane firmy. Takýto pomer by mal platit' 2 roky. [2]

V d'alších fázach úpravy daňovej asignácie daňovník, ktorý je právnickou osobou, bude oprávnený vyhlásit' $\mathrm{v}$ daňovom priznaní za zdaňovacie obdobia končiace najneskôr 31 . decembra 2012 až 31. decembra 2014 v lehote na podanie daňového priznania (v rokoch 2013 až 2015), že podiel zaplatenej dane sa má poukázat' do výšky $1,5 \%$ ním určeným prijímatel'om. Podminkou však je, že daňovník daruje finančné prostriedky najmenej vo výške zodpovedajúcej $1 \%$ zaplatenej dane v zdaňovacom období alebo najneskôr v lehote na podanie daňového priznania, ktorého sa vyhlásenie bude týkat', ním určeným daňovníkom, ktorí nie sú založení alebo zriadení na podnikanie na účely taxatívne vymedzené v zákone o dani z príjmov. Ak daňovník neposkytne $\mathrm{v}$ tejto výške prostriedky ako dar, je oprávnený vyhlásit' $\mathrm{v}$ daňovom priznaní $\mathrm{v}$ lehote na podanie daňového priznania, že podiel zaplatenej dane sa má poukázat' nim určeným prijímatel'om len do výšky $1 \%$ zaplatenej dane. Znamená to, že takýto postup uplatní daňovník, ktorý je právnickou osobou pri podávaní daňových priznaní v rokoch 2013, 2014 a 2015 za zdaňovacie obdobia končiace 2012, 2013 a 2014.

Za zdaňovacie obdobia končiace najneskôr 31. decembra 2015, 2016, 2017 a 2018 sa podiel zaplatenej dane zníži do výšky $1 \%$ za predpokladu, že daňovník daroval finančné prostriedky zodpovedajúce 1,5\% zaplatenej dane ním určeným daňovníkom nezriadeným na podnikanie. Ak tak neurobí, podiel zaplatenej dane bude poukázaný len do výšky 0,5\% zaplatenej dane.

V zdaňovacom období končiacom 31. decembra 2019 bude podiel zaplatenej dane u daňovníka, ktorý je právnickou osobou do výšky $0,5 \%$ zaplatenej dane bez ustanovenej podmienky poskytnutia finančných prostriedkov ako dar. [4]

Jedným z ciel'ov takto rozplánovaného zrušenia daňovej asignácie je zvýšenie filantropného správania firiem. $Z$ minuloročného prieskumu o stave firemnej filantropie na Slovensku vyplýva, že firmám ktoré sa do prieskumu zapojili darcovstvo nie je cudzie. Toto ted a mo ̌̌ byt' smer ak o zvýšit' a naštartovat' filantropné správanie firiem z vlastných finančných prostriedkov a vylúči sa tak zneužívanie daňovej asignacie spoločnost'ami vo svoj vlastný prospech.

\section{Literatúra}

[1] Raková, Lubomíra: Dve percentá z dane pomaly končia. [Online]. [Citované 2010-0508]. Dostupné na: <http://hnonline.sk/ekonomika/c1-37941130-dve-percenta-z-dane-sapomaly-koncia>

[2] Vyhlásenie o poukázaní sumy vo výške 2\% zaplatenej dane. [Online]. [Citované 201005-09]. Dostupné na:

<http://www.drsr.sk/drsr/slovak/poskytovanie_informacii/media/data/ts10_2perc.pdf> 
[3] Informácia o splnení uznesenia vlády Slovenskej republiky č.980 zo 66. rokovania vlády SR konaného v dňoch 10. a 11. novembra 1999

[4] Faiglová, S., Haňdiak, P., Andrejkovič, M: Manuál pre prijímatel'ov $2 \% \mathrm{z}$ dane. [Online]. [Citované 2010-05-04]. Dostupné na: <http://www.rozhodni.sk/documents/42-78-6853manual2percent.pdf>

[5] Sedláčková, H.: Daňové asignace jako nástroj financování neziskového sektoru: bakalárska práca. Brno: Masarykova univerzita v Brne. 2005. 49s.

[6] Aktuálna legislatíva 2\% z dane. [Online]. [Citované 2010-05-11]. Dostupné na: <http://www.rozhodni.sk/index.php?aktualna_legislativa_2\%_z_dane/sl/75>

[7] Použitie podielu zaplatenej dane na osobitné účely (2\% dane). [Online]. [Citované 201005-11]. $<$ http://portal.gov.sk/Portal/sk/Default.aspx/Zep/Board/Modules/Zep/Default.aspx?CatID $=41 \&$ etype $=2 \&$ aid $=803>$ 